\title{
Experimental study on nitrification in a submerged aerated biofilter
}

\author{
G. Farabegoli, A. Chiavola, E. Rolle and S. Stracquadanio \\ Department of Hydraulics, Transportation and Roads, Faculty of Engineering, University of Rome "La \\ Sapienza", 18 via Eudossiana, 00184 Rome, Italy (E-mail: geneve.farabegoli@polimi.it; \\ agostina.chiavola@uniroma1.it; enrico.rolle@uniroma1.it; stefanostracquadanio@tiscali.it)
}

\begin{abstract}
The aim of the present work was to evaluate the performance of a semi-pilot scale BAF in order to obtain a highly polished effluent in terms of removal of organic matter, suspended solids and ammonia and to observe the influence of temperature, $\mathrm{pH}$ and nitrite accumulation on the nitrification process. The ammonia removal efficiency during summer and winter and the nitrite accumulation in presence of free ammonia were observed. The biomass density was measured at different filter bed heights and the sludge production from the effluent of the backwashing water was evaluated. The results obtained were used to calibrate a mathematical model for the prediction of the ammonia removal profile in the filter bed and of biomass thickness.
\end{abstract}

Keywords Biological Aerated Filter (BAF); biomass; free ammonia; mathematical model; nitrite

\section{Introduction}

Recently, the need for reducing plant areas and reactor volumes, the increase of the management costs for wastewater treatment, and the necessity to improve the performances of the existing plants to comply with the more strict effluent standards of Italian law (D.Lgs.152/99) regarding COD, nutrients and suspended solids, have led to consideration of the advantages of the attached growth biomass treatment processes compared to the suspended biomass processes. The attached biomass reactors can remove simultaneously organic matter, suspended solids and organic and ammonia nitrogen. In particular a biological aerated filter (BAF) can entrap the particulate COD and the solid particles that are successively removed by a backwash step, while the soluble COD is degraded by microorganisms growing on the filter media (Grady et al., 1999).

The aim of the present work was to evaluate the performance of a semi-pilot scale BAF in terms of removal of organic matter, ammonia and suspended solids and to observe the influence of temperature, $\mathrm{pH}$ and nitrite accumulation on the nitrification process. Two periods with different influent flow-rates have been studied. In the first period, with an influent flow-rate of $25 \mathrm{l} / \mathrm{h}$, the main aim was the evaluation of the ammonia removal efficiencies during summer and winter conditions. In the second period, with an influent flowrate of $12 \mathrm{l} / \mathrm{h}$, the effect of free ammonia on the nitrification process and the nitrite accumulation have been studied within two phases at $20^{\circ} \mathrm{C}$ and $25^{\circ} \mathrm{C}$ respectively.

\section{Methods}

Description of the semi-pilot scale BAF

The research was performed in a semi-pilot scale downflow biofilter $(1.8 \mathrm{~m}$ height, $15 \mathrm{~cm}$ internal diameter and $80 \mathrm{~cm}$ filter media height) filled with expanded clay (Farabegoli et al, 2003). Eight liquid phase sampling points were placed from 5 to $75 \mathrm{~cm}$, every $10 \mathrm{~cm}$, along the filter bed height, and four solid phase sampling points were at 10,30,50 and $70 \mathrm{~cm}$ from the bottom of the filter bed. The BAF was set up by the municipal wastewater treatment plant of North Rome, managed by ACEA S.p.A. The BAF was fed with the effluent from 
the primary settling tank with $150 \mathrm{mg} \mathrm{COD} / 1,40 \mathrm{mg} \mathrm{NH}_{4}-\mathrm{N} / 1$ and $90 \mathrm{mg} \mathrm{TSS} / \mathrm{l}$. Oxygen was supplied by blowing air through four porous stones located at the bottom of the filter bed, in order to keep DO concentration along the filter height at $2-2.5 \mathrm{mg} / \mathrm{l}$. Sludge coming from the oxidation process of the wastewater treatment plant with $450 \mathrm{mg} \mathrm{TSS} / \mathrm{l}$ and 380 $\mathrm{mg}$ VSS/l was used as seed. As a consequence of the activity of the microorganisms attached to the filter packed media, an increase of the biofilm thickness and a decrease of the bed porosity were observed. Once the head loss over the filter bed reached the maximum level a backwashing phase occurred. This phase was performed with air (20 1/min), to detach the excess biomass, water $(700 \mathrm{l} / \mathrm{h})$ and air $(20 \mathrm{l} / \mathrm{min})$, in order to fluidize and expand the filter bed volume of $15-20 \%$ and only water $(700 \mathrm{l} / \mathrm{h})$ to transport the detached biomass out of the filter. In order to reuse the effluent water of the BAF, part of it was used as backwashing water. A hydrostatic probe connected with a controller to a PC monitored the headloss trend. A controller box connected to a computer managed the influent feed, the aeration system and the backwashing phase.

\section{Measurements and analysis}

During experimental activity the most important parameters that could influence process efficiency and organic substance removal were evaluated. Influent, liquid and solid along the filter bed height and effluent samples were analyzed for COD, Total and Volatile Suspended Solids (TSS, VSS), ammonia, nitrate and nitrite using the Standard Methods for the Examination of Water and Wastewater (1995). Liquid samples have been taken from 5, 35,55 and $75 \mathrm{~cm}$ from the bottom of the filter bed height. The VAS (Volatile Attached Solids), sampling the biomass at two different filter bed heights ( 30 and $70 \mathrm{~cm}$ from the bottom), were measured by the gravimetric method. Head loss over the whole filter bed, DO, temperature and $\mathrm{pH}$ were monitored.

\section{Results and discussion}

Ammonia removal

During the first period, with an influent flow rate of $25 \mathrm{l} / \mathrm{h}, \mathrm{COD}$ and ammonia removal efficiencies were studied during summer (average temperature $25^{\circ} \mathrm{C}$ ) and winter (average temperature $12^{\circ} \mathrm{C}$ ). In summer the average COD removal efficiency was $62 \%$ and in winter $43 \%$. The effect of temperature on the nitrification process has been much higher than expected; the average ammonia removal efficiency has been $82 \%$ in summer and $32 \%$ in winter. Sampling and analyzing the liquid at four different heights, the $\mathrm{NH}_{4}{ }^{+}-\mathrm{N}$ profile in the filter bed can be represented. Figure 1 shows the ammonia trend during summer and winter conditions; in winter the nitrification process along the entire filter bed can be described by a zero order kinetic, with a linear curve. In summer, for the influent zone a zero order kinetic appeared to be still valid, but the ammonia removal efficiency from the central part of the filter to the bottom, receiving a low substrate concentration, could be

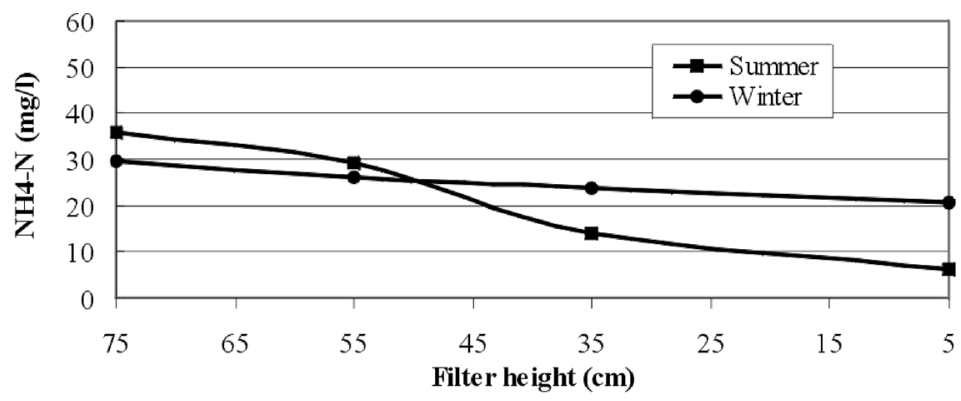


better described by a first order kinetic. This could also be due to the higher competition between heterotrophic and autotrophic microorganisms in the upper zone of the filter. The average effluent nitrates were $18 \mathrm{mg} \mathrm{NO}_{3}-\mathrm{N} / \mathrm{l}$ during summer and $4 \mathrm{mg} \mathrm{NO}_{3}-\mathrm{N} / \mathrm{l}$ in winter. Average $\mathrm{pH}$ decreased from 7.8 to 7.7 along the filter height, according to the production of acidity during the nitrification process.

During the second period, with an influent flow rate of $12 \mathrm{l} / \mathrm{h}$, two phases at $20^{\circ} \mathrm{C}$ and $25^{\circ} \mathrm{C}$ have been studied. A temperature increase of $5^{\circ} \mathrm{C}$ has increased the COD removal efficiency from $60 \%$ to $70 \%$. The ammonia removal efficiency increased from $80 \%$ to 95\%. The ammonia profile during the two phases is represented in Figure 2. Both trends are very similar, with the exception of the data related to the upper part of the filter. Probably, as said before, at $20^{\circ} \mathrm{C}$ the competition between heterotrophs and nitrifiers is high; this competition becomes less pronounced at $25^{\circ} \mathrm{C}$, due to the higher activity of the autotrophs. The average effluent nitrates were higher at $20^{\circ} \mathrm{C}$ than at $25^{\circ} \mathrm{C}$ because, in this second phase, the influent ammonia has been lower, as shown in Figure 2.

The ammonia removal process occurred in the entire filter height, as shown in Figures 1 and 2, and the presence of nitrifiers in all the BAF is evident. This is in accordance with other studies that indicated the presence of a spatial distribution of microorganisms along the filter height when the ratio COD: $\mathrm{NH}_{4}^{+}-\mathrm{N}$ is over four (Fdz-Polanco et al., 2000).

\section{Free ammonia and nitrite accumulation}

Free ammonia inhibition on biological activity of nitrifying bacteria is well known. Temperature, $\mathrm{pH}$ and ammonium concentrations are the most important parameters that can influence the equilibrium controlling the free ammonia concentration:

$\mathrm{NH}_{4}{ }^{+}+\mathrm{OH}^{-} \leftrightarrow \mathrm{NH}_{3 \text { free }}+\mathrm{H}_{2} \mathrm{O}$

The dependence of free ammonia concentration on the previous parameters can be described with the following equations:

$$
\begin{aligned}
& {\left[\mathrm{NH}_{3}-N\right]_{\text {free }}=\frac{\left[\mathrm{NH}_{4}-N\right] \cdot 10^{p H}}{\left(\frac{K_{a}}{K_{w}}\right)+10^{p H}}} \\
& \frac{K_{a}}{K_{w}}=\exp [6334 /(273+T)]
\end{aligned}
$$

with $K_{\mathrm{a}}$ and $K_{\mathrm{w}}$ the ammonia and water ionization constants, and $T$ expressed in ${ }^{\circ} \mathrm{C}$.

For reasonable liquid and air surface velocity, a BAF system can be considered approximately as a PFR (Plug Flow Reactor) (Fdz-Polanco, 1994b). Therefore, pH and ammonia

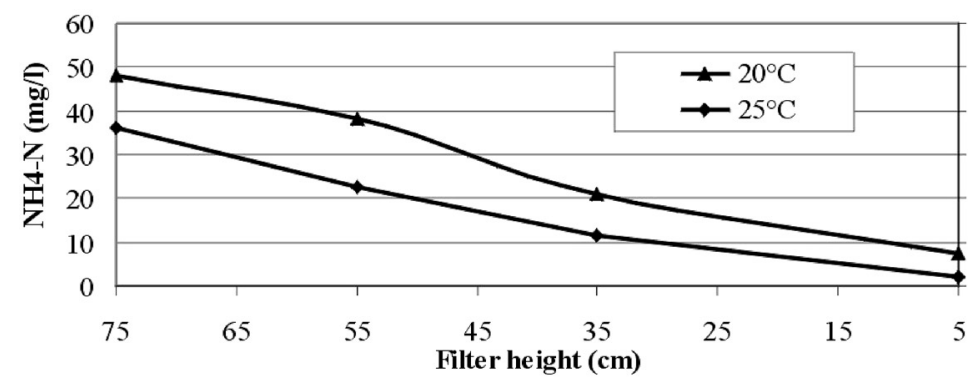

Figure 2 Ammonia profile at $20^{\circ} \mathrm{C}$ and $25^{\circ} \mathrm{C}$, at $12 \mathrm{l} / \mathrm{h}$ 
concentration gradients are produced in the filter bed, with maximum values near the influent zone; consequently a free ammonia gradient will be present, higher at the top and lower at the bottom of the BAF. The inhibiting concentration is about $10 \mathrm{mg} \mathrm{NH}_{3 \text { free }} \mathrm{-N} / \mathrm{l}$ for Nitrosomonas and 0.1-1 mg NH 3 free $-\mathrm{N} / \mathrm{l}$ for Nitrobacter (Anthonisen et al., 1976). Further studies have shown the importance of referring to the "specific free ammonia" concentration expressed as $\mathrm{mg} \mathrm{NH}_{3 \text { free }}-\mathrm{N} / \mathrm{gVAS}$. The threshold value found for Nitrobacter is $0.5 \mathrm{mg}$ $\mathrm{NH}_{3 \text { free }}$-N/gVAS (Fdz-Polanco et al., 1994a). When Nitrobacter activity is even partially inhibited, an accumulation of nitrite occurs, and they are not further oxidized to nitrates. In our research a decreasing free ammonia concentration along the filter height occurred, as expected (Figures 3, 4 and 5).

In the first period, during winter conditions, nitrites increased with the filter height and the effluent value was about $1.5 \mathrm{mg} \mathrm{NO}_{2}-\mathrm{N} / \mathrm{l}$; the free ammonia concentration was always in the range $0.1-1 \mathrm{mg} \mathrm{NH}_{3 \text { free }}-\mathrm{N} / \mathrm{l}$ along the entire height of the filter. Both nitrite and free ammonia profiles are represented in Figure 3. The effluent nitrite concentration was low because of the winter temperature. The nitrite-increasing trend along the filter height shows the preponderance of the inhibition effect over the nitrification process.

In the second period both at $20^{\circ} \mathrm{C}$ and at $25^{\circ} \mathrm{C}$, the free ammonia concentration was in the range $0.1-1 \mathrm{mg} \mathrm{NH}_{3 \text { free }}-\mathrm{N} / 1$ from $55 \mathrm{~cm}$ to the bottom of the filter; consequently the Nitrobacter activity was partially inhibited with the exception of the upper zone, near the entrance. Nitrite profiles were very similar in both phases showing a bell-shaped curve; the maximum $\mathrm{NO}_{2}-\mathrm{N}$ values were reached at $35 \mathrm{~cm}$ and at $55 \mathrm{~cm}$, at $20^{\circ} \mathrm{C}$ and at $25^{\circ} \mathrm{C}$ respectively (Figures 4 and 5). The temperature increase of $5^{\circ} \mathrm{C}$ caused a translation of the nitrite peak towards the entrance.

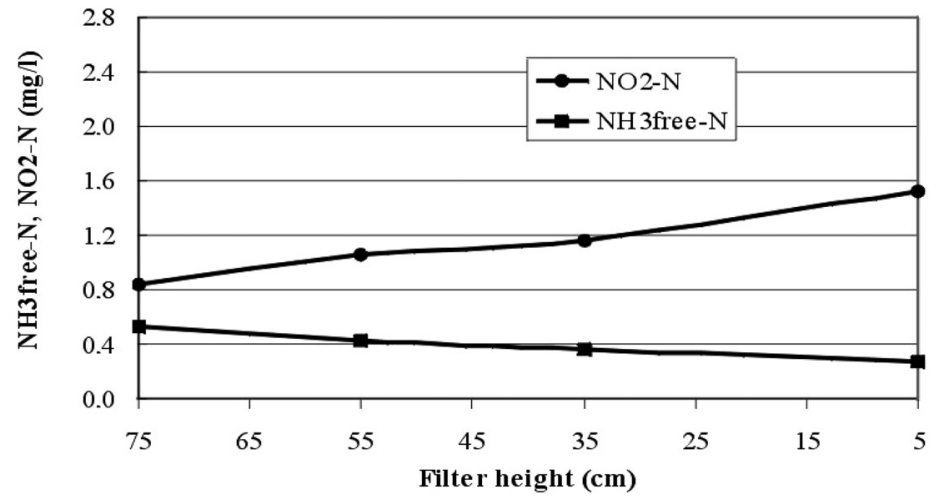

Figure 3 Nitrite and free ammonia profiles in winter conditions at $25 \mathrm{l} / \mathrm{h}$

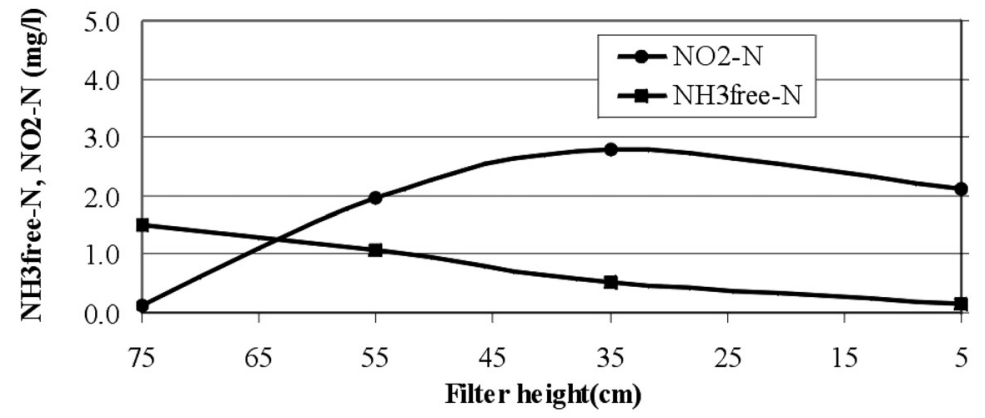




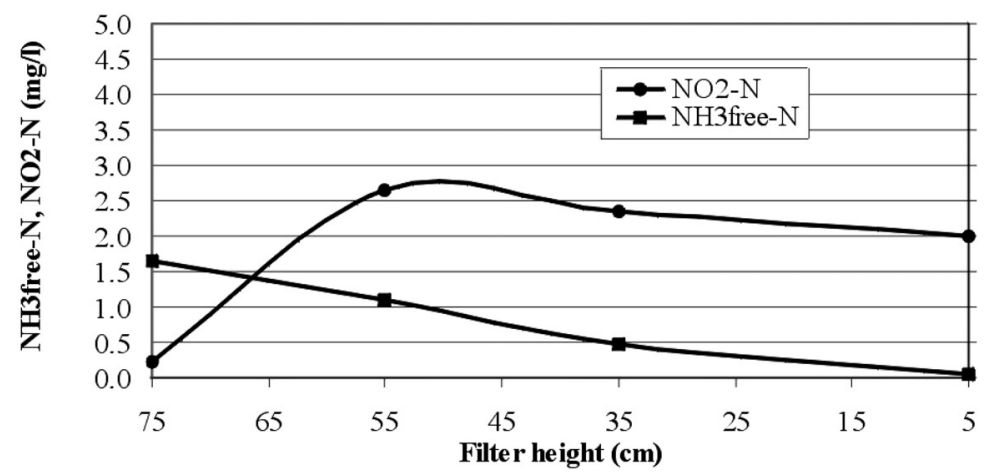

Figure 5 Nitrite and free ammonia profiles at $25^{\circ} \mathrm{C}$ and $12 \mathrm{l} / \mathrm{h}$

Since the free ammonia inhibition and the nitrification process are functions of temperature, the translation of the nitrite peak towards the entrance of the filter could be due to the greater and faster production of nitrite at $25^{\circ} \mathrm{C}$ rather than at $20^{\circ} \mathrm{C}$, which is later accumulated because of the inhibition effect of free ammonia over the Nitrobacter. Therefore the nitrite profile of Figure 3 could be the initial part of the nitrite curves of Figures 4 and 5.

\section{Biomass density and sludge production}

During the second period, the VAS were analyzed at two different filter bed heights ( 30 and $70 \mathrm{~cm}$ from the bottom) to determine the biomass density. The biomass has been referred to as the mass of sampled support and the biomass density can be expressed as $\mathrm{mg}$ VAS/g support. The results obtained show similar average values in both phases $\left(20^{\circ} \mathrm{C}\right.$ and $\left.25^{\circ} \mathrm{C}\right)$ in the upper zone of the filter (9-10 mg VAS/g support). It is necessary to remember that in this upper part of the filter more influent suspended solids are entrapped by the support and a greater amount of suspended biomass has been found, producing an approximation in the calculation. In the lower part of the filter, where the results are more reliable, the effect of the temperature increase on the biomass density was more evident; the average value was $6.8 \mathrm{mg} \mathrm{VAS} / \mathrm{g}$ support at $20^{\circ} \mathrm{C}$ and $11.7 \mathrm{mg} \mathrm{VAS} / \mathrm{g}$ support at $25^{\circ} \mathrm{C}$. However, the biomass density values found in this research are significantly higher than those obtained by FdzPolanco studying a BAF fed with synthetic wastewater (Fdz-Polanco et al., 2000).

The "specific free ammonia" concentration has been evaluated. For a nitrite accumulation of $20 \%$, expressed as $\mathrm{NO}_{2}-\mathrm{N} /\left(\mathrm{NO}_{2}-\mathrm{N}+\mathrm{NO}_{3}-\mathrm{N}\right)$, a specific free ammonia concentration of $0.25 \mathrm{mg} \mathrm{NH} \mathrm{N}_{3 \mathrm{ree}}-\mathrm{N} / \mathrm{gVAS}$ has been found, in accordance with other authors (FdzPolanco et al., 1997). The sludge production from the effluent of the backwashing water was evaluated. The average influent suspended solids were $90 \mathrm{mg}$ TSS/l (60 mg VSS/l), the average effluent solids were $35 \mathrm{mg} \mathrm{TSS} / \mathrm{l}$ (30 mg VSS/l) and the average sludge production was $4 \mathrm{~g} \mathrm{VSS} / \mathrm{d}$.

\section{Mathematical model}

The data obtained during the first period were used for simulation with a numerical model (Viotti et al., 2002). This model allows the calculation of the $\mathrm{COD}$ and $\mathrm{NH}_{4}{ }^{+}$profile along the filter height and inside the biofilm thickness and simulates filter clogging due to the biomass growth. The model is based on double saturation Michaelis-Menten kinetics and considers the resistance to mass transport both within and outside the bioparticles. The model output is the result of the differential equation system that describes the filter performance (Sbaffoni, 2000).

The model was previously calibrated and then used to simulate $\mathrm{COD}$ and $\mathrm{NH}_{4}{ }^{+}$profiles 


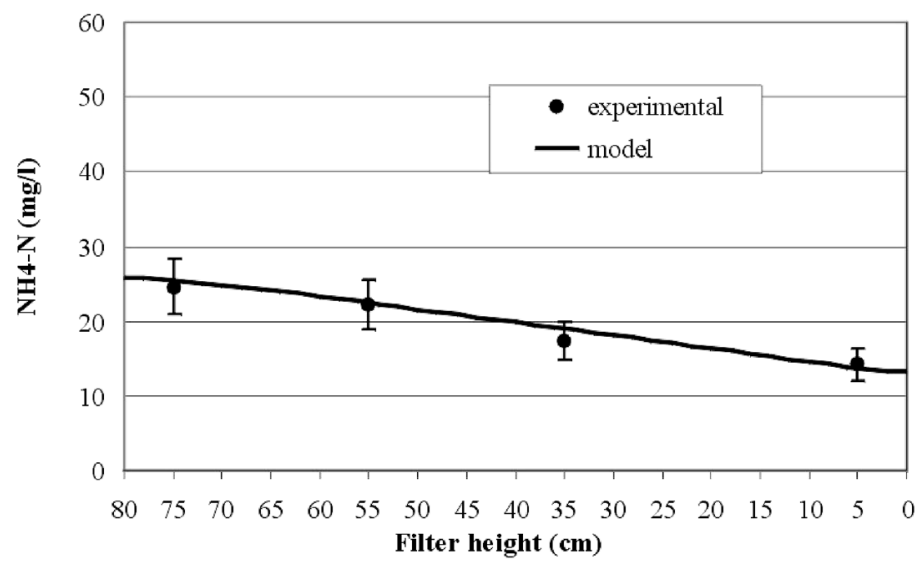

Figure 6 Simulated and experimental values for $\mathrm{NH}_{4}-\mathrm{N}$ at $25 \mathrm{l} / \mathrm{h}$

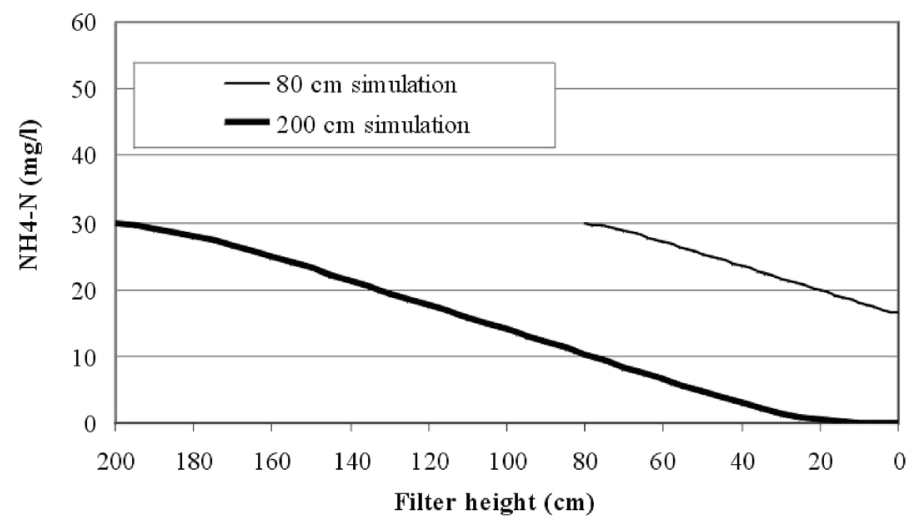

Figure 7 Simulation of the optimal filter height for nitrification

along the filter height (in Figure 6 is reported the ammonia profile along the filter height). The biomass thickness predicted by the model was about $320 \mu \mathrm{m}$.

Afterwards the model was used to calculate the optimal height of the semi-pilot BAF to obtain over $80 \%$ ammonia removal efficiency in the worst conditions i.e. in winter and with a flow rate of $25 \mathrm{l} / \mathrm{h}$. In Figure 7 is represented the simulation of the model with an optimal filter height of $200 \mathrm{~cm}$.

\section{Conclusions}

This study has evaluated the performance of a semi-pilot scale BAF reactor fed with real urban wastewater. The effect of temperature on the nitrification process has been much higher than expected; the average ammonia removal efficiency has been $82 \%$ in summer and $32 \%$ in winter. Higher organic and ammonia removal rates were obtained at higher hydraulic retention time (HRT). At low HRT and during winter conditions, a nitrite accumulation occurred in the presence of free ammonia, increasing with the filter bed height; at high HRT, the nitrite profile along the filter height showed a bell-shaped curve with the maximum values at $35 \mathrm{~cm}$ and at $55 \mathrm{~cm}$ from the bottom of the filter, at $20^{\circ} \mathrm{C}$ and at $25^{\circ} \mathrm{C}$ respectively. The temperature increase of $5^{\circ} \mathrm{C}$ caused a translation of the nitrite peak towards the entrance of the filter.

The biomass density values found in this study are significantly higher than those obtained by other authors studying a BAF fed with synthetic wastewater (Fdz-Polanco et al., 2000). 
The experimental data were used for simulation with a numerical model; the simulated ammonia profile fitted the experimental data very well and an indirect measure of the active biofilm thickness could be obtained. Furthermore, the model allowed calculation of the optimal height of the semi-pilot BAF in order to obtain over $80 \%$ ammonia removal efficiency at low HRT and in winter conditions.

\section{References}

Anthonisen, A.C., Loehr, R.C., Prakasam, T.B.S. and Srinath, E.G. (1976). Inhibition of nitrification by ammonia and nitrous acid. Journal of Water Pollution Control Federation, 48, 835-852.

Farabegoli, G., Carucci, A., Gandolfo, G., Rolle, E and Viotti, P. (2003). Experimental study on carbon removal in biological aerated filters. Water Science \& Technology, 48(11-12), 235-242.

Fdz-Polanco, F., Villaverde, S. and Garcia, P.A. (1994a). Temperature effect on nitrifying bacteria activity in biofilters: activation and free ammonia inhibition. Water Science \& Technology, 30(11), 121-130.

Fdz-Polanco, F., Villaverde, S. and Garcia, P.A. (1994b). Influence of design and operation parameters on the flow pattern of a submerged biofilter. J. Chem. Tech. Biotechnol., 61, 153-158.

Fdz-Polanco, F., Villaverde, S. and Garcia, P.A. (1997). Influence of pH over nitrifying biofilm activity in submerged biofilters. Water Research, 31(5), 1180-1186.

Fdz-Polanco, F., Mendez, E., Uruena, M.A., Villaverde, S. and Garcia, P.A. (2000). Spatial distribution of heterotrophs and nitrifiers in a submerged biofilter for nitrification. Water Research, 34(16), 4081-4089.

Grady, C.P.L., Daigger, G.T. and Lim, H.C. (1999). Biological Wastewater Treatment. Marcel Dekker Inc.

Sbaffoni, S. (2000). Modellizzazione del processo di biofiltrazione: sviluppo del codice numerico e analisi di sensitività. Master thesis, Department of Hydraulics, Transportation and Roads, University of Rome.

Standard Methods for the Examination of Water and Wastewater (1995). 19th edn, American Public Health Association/American Water Works Association/Water Environment Federation, Washington DC, USA.

Viotti, P., Eramo, B., Boni, M.R., Carucci, A., Leccese, M. and Sbaffoni, S. (2002). Development and calibration of a mathematical model for the simulation of the biofiltration process. Advances in Environmental Research, 7(1), 11-33. 